\title{
ANTIOXIDATIVE CHARACTERISTICS OF BEVERAGES MADE FROM A MIXTURE OF LEMONGRASS EXTRACT AND GREEN TEA
}

\author{
[Studi Karakteristik Antioksidan Minuman Campuran Ekstrak Serai dan Teh Hijau] \\ Jeremia Manuel Halim*, W. Donald R. Pokatong and Jessica Ignacia \\ Food Technology Department, Universitas Pelita Harapan, Karawaci, Tangerang
}

Accepted July $22^{\text {th }} 2013$ / Approved January $08^{\text {th }} 2014$

\begin{abstract}
Combination of lemongrass extract and green tea infusion is expected to produce functional beverage that has potential antioxidant activity as compared to individual materials. This research was aimed to investigate the appropriate solvent type and extraction methods to produce lemongrass extract with highest antioxidant activity and also to investigate the antioxidant characteristic of beverages prepared from a mixture of lemongrass extract and green tea. Lemongrass were subjected to extraction under reflux and maceration using three type of solvents (distilled water, ethanol, and ethyl acetate). The resulting extracts were assessed for their total phenolic content, total flavonoid content, and antioxidant activity. Extraction under reflux and using ethanol as solvent resulted in extract with best antioxidant activity $\left(\mathrm{IC}_{50}=158.70 \pm 47.88 \mathrm{mg} / \mathrm{L}\right.$ for reflux method and $103.73 \pm 8.03 \mathrm{mg} / \mathrm{L}$ for ethanol). This extract was combined with green tea with several ratios (lemongrass extract to green tea [w/w] = $1: 3 ; 1: 2 ; 1: 1 ; 2: 1 ; 3: 1)$. Four level of stevia were used in the beverages $(0,200,400,600 \mathrm{ppm})$. Beverages made with lomogass: tea ratio of $1: 3$ and $1: 1(\mathrm{w} / \mathrm{w})$ and $600 \mathrm{ppm}$ stevia turned out to be beverages with the highest antioxidant activity $\left(\mathrm{IC}_{50}=271.83 \pm 44.48 \mathrm{mg} / \mathrm{L}\right.$ and $287.15 \pm 36.25 \mathrm{mg} / \mathrm{L}$ for ratio $1: 3$ and 1:1 [w/w] consecutively, $301.59 \pm 80.89 \mathrm{mg} / \mathrm{L}$ for stevia level $600 \mathrm{ppm})$. Hedonic testing on beverages revealed that beverage made from lemongrass: tea ratio 1:1 [w/w] ratio with addition of stevia at $600 \mathrm{ppm}$ is the most preferred based on colour, aroma, and overall acceptance.
\end{abstract}

Keywords: antioxidant, extraction, green tea, lemongrass

\section{ABSTRAK}

Kombinasi ekstrak serai dan teh hijau diharapkan dapat menghasilkan minuman fungsional yang memiliki potensi antioksidan lebih tinggi dari penyusunnya. Penelitian ini bertujuan untuk mempelajari jenis pelarut dan metode ekstraksi yang dapat menghasilkan ekstrak serai dengan aktivitas antioksidan tertinggi serta mempelajari karakteristik antioksidan dari minuman campuran ekstrak serai dan teh hijau. Serai diekstraksi dengan metode refluks dan maserasi menggunakan tiga jenis pelarut (akuades, etanol, dan etil asetat). Kandungan total fenol, flavonoid, dan aktivitas antioksidan dari ekstrak yang dihasilkan diukur. Ekstraksi dengan refluks menggunakan pelarut etanol menghasilkan ekstrak dengan aktivitas antioksidan tertinggi (IC $C_{50}=158.70 \pm 47.88 \mathrm{mg} / \mathrm{L}$ untuk metode refluks dan $103.73 \pm 8.03 \mathrm{mg} / \mathrm{L}$ untuk etanol). Ekstrak ini dikombinasikan dengan teh hijau dalam beberapa rasio (ekstrak serai: teh hijau $[w / w]=1: 3 ; 1: 2 ; 1: 1 ; 2: 1 ; 3: 1)$. Empat level stevia digunakan dalam minuman (0, 200, 400, 600 ppm). Minuman dengan rasio 1:3 dan 1:1 [w/w], serta level stevia 600 ppm merupakan minuman dengan aktivitas antioksidan tertinggi (IC50=271.83 $\pm 44.48 \mathrm{mg} / \mathrm{L}$ dan 287.15 $\pm 36.25 \mathrm{mg} / \mathrm{L}$ untuk rasio 1:3 dan 1:1 [w/w] berurutan, serta 301.59 $\pm 80.89 \mathrm{mg} / \mathrm{L}$ untuk level stevia 600 ppm). Uji hedonik menunjukkan bahwa minuman dengan rasio 1:1 [W/W] dengan level stevia 600 ppm adalah yang paling disukai dari segi warna, aroma, dan penerimaan keseluruhan.

Kata kunci: antioksidan, ekstraksi, teh hijau, serai

\section{INTRODUCTION}

Antioxidant acts as radical scavenger which donates hydrogen ion to neutralize free radical in human cells and inhibits occurence of cancer. Incorporation of antioxidant in the diet might help in reducing oxidative stress and occurrence of degenerative disease such as cancer (Cheel et al. 2005). Lemongrass (Cymbopogon spp.) plant grows in tropical and subtropical region and is commonly cultivated as spices or essential oil. Lemongrass extract was reported to inhibit colon cancer in animal models (Puatanachokchai et al. 2002).

Paper has been presented at International Conference on 'Future of Food Factors', October 3-4, 2012, Jakarta, Indonesia

${ }^{*}$ Corresponding Author:

E-mail: jeremia.halim@uph.edu, phone: 021-5460901 ext.1248
Juntachote et al. (2006) reported that ethanolic extract of lemongrass contains 535.44 to $1007.35 \mathrm{mg} / 100 \mathrm{~g}$ total phenolic and have 80.38 to $93.31 \%$ antioxidant activity.

Other than lemongrass extract, green tea infusion also has high antioxidant activity. As mentioned by Kirakosyan et al. (2010), pairs of compounds with high antioxidant capacity showed strong synergistic interactions. This finding leads to possibility of synergistic interactions between lemongrass extract and green tea in terms of antioxidant activity. Addition of stevia as sweetener was expected to mask undesirable taste that might be contributed by mixture of lemongrass extract and green tea. Lemongrass extract is a potential natural antioxidant however a proper solvent and method of extraction are yet to be determined. Madan et al. (2010) mentioned that steviol glycoside as main component of stevia has antioxidant activity. 
Addition of stevia might influence antioxidant characteristics of beverages. This research aimed to determine solvent and extraction method that result in lemongrass extract with the highest antioxidant activity and to study antioxidant characteristics of beverages prepared from a mixture of lemongrass extract and green tea with addition of stevia.

\section{MATERIALS AND METHODS}

\section{Materials}

Materials used in this research were lemongrass leaves from a plantation in Garut-East Java, commercial stevia powder 90\% Aoxing, green tea from Gunung Mas tea plantation, and drinking water. The lemongrass was dried using cabinet dryer $\left(40^{\circ} \mathrm{C}, 24 \mathrm{~h}\right)$, grinded, and sieved. Particle size of 30 mesh was considered as sufficient for extraction of lemongrass antioxidant. It referred to particle size of wheat bran in extraction of wheat bran antioxidant (Yu, 2008).

Extract preparation (modified from Cheel et al. (2005), Jutanchote et al. (2006), Tachakittirungrod et al. (2007), and $\mathrm{Yu}(2008))$

The solvents used were ethanol $80 \%$, ethyl acetate $80 \%$, and distilled water. Concentration of solvent for optimum concentration of ethanol extraction of lemongrass as mentioned by Jutanchote et al. (2006), is 1:10 [w/v] (powder : solvent). Two types of extraction methods were applied in this study were maceration $\left(25^{\circ} \mathrm{C}, 48 \mathrm{~h}\right)$ (modified from Tachakittirungrod et al. 2007 in terms of sample amount) and reflux extraction (boiled $30 \mathrm{~min}$ ) (modified from Cheel et al. 2005 in terms of solvent type).

The resulted extracts were filtered using Whatmann no.1 and were concentrated using rotary evaporator at $40^{\circ} \mathrm{C}$. The concentrated extracts were analyzed for their moisture content yield (\%), total phenolic content, total flavonoid content, antioxidant activity, phytochemical test, and toxicity test.

\section{Beverages preparation (Tagami et al. 2012)}

The beverage was prepared from combination of lemongrass extract and green tea with addition of stevia powder as sweetener to mask undesirable taste. The amount of stevia powder added was based on regulation by World Health Organization (WHO, 2009). The ratios of lemongrass extract to green tea were 1:1; 1:2, 1:3, 2:1, 3:1 [w/w] (Kirakosyan et al. 2010). The mixture of lemongrass extract and green tea leaves was brewed with water at $90^{\circ} \mathrm{C}$ for 1 minutes. The ratio of green tea to water is 1 to $43(\mathrm{w} / \mathrm{v})$. The brewing method was adopted from Standard Table of Food Composition in Japan (Tagami et al. 2012). The beverages were analyzed for total phenolic content, flavonoid, and antioxidant activity. Hedonic test was done for sample with the best characteristics.

\section{Antioxidant activity using DPPH method (Shim and Lim, 2009)}

Sample was measured at $0.1 \mathrm{~mL}$ and was mixed with 2.9 $\mathrm{mL}$ of $0.1 \mathrm{mM}$ of 2,2-diphenyl-1-picrylhydrazyl radical (DPPH). The mixture was homogenized by using vortex. Afterwards the mixture was put aside in dark place for 30 minutes. The absorbance of the mixture was measured by using visible spectro-photometer at wavelength $517 \mathrm{~nm}$. The control was made by mixing $0.1 \mathrm{~mL}$ of ethanol and $2.9 \mathrm{~mL}$ of $0.1 \mathrm{mM} \mathrm{DPPH}$.

Total phenolic content using Folin-Ciocalteu method (Makkar et al. 2007) (modified in terms of sample amount)

The sample was put in reaction tube $(1 \mathrm{ml})$ and was added with $0.5 \mathrm{~mL}$ of $1 \mathrm{~N}$ Folin-Ciocalteu reagent and $2.5 \mathrm{~mL}$ of $20 \%$ sodium carbonate solution. The solution was mixed well using vortex and incubated under dark conditions for 40 minutes. The absorbance of the solution was measured using visible spectrophotometer with wavelength $725 \mathrm{~nm}$. The total phenolics content was determined from calibration curve with tannic acid as a standard.

\section{Total flavonoid content (Meda et al. 2005)}

For total flavonoid content analysis, $5 \mathrm{~mL}$ of sample was mixed with $5 \mathrm{~mL}$ of $2 \%$ aluminum chloride. This mixture was mixed well by using vortex and incubated for 10 minutes at room temperature. Absorbance of mixture was measured by using visible spetrophotometer at $415 \mathrm{~nm}$. Blank was prepared from 5 $\mathrm{mL}$ sample and $5 \mathrm{~mL}$ ethanol. Calibration curve was made by using quercetin as standard.

\section{Phytochemical test (Harborne, 1996)}

Qualitative determination was conducted in BALITTRO (Balai Penelitian Tanaman Obat dan Aromatik), Bogor. Lemongrass extract was tested regarding presence of tannin, phenolic, flavonoid, saponin, triterpenoid, steroid, glycosides, and alkaloids according to the procedure from Harborne (1996).

\section{Toxicity test (Juniarti et al. 2009)}

The toxicity test of lemongrass extract was done at LPSB (Laboratorium Pusat Studi Biofarmaka) IPB, Bogor. Brine Shrimp Lethality Test (BSLT) method was applied to measure lethality level of the brine shrimp larvae treated with lemongrass extract. Toxicity of extract was stated as on $\mathrm{LC}_{50}$ value (concentration where sample causes $50 \%$ death of shrimp larvae).

\section{Consumer acceptance test by 7 hedonic scale (Moskowitz et al. 2006)}

The consumer acceptance was evaluated regarding colour, aroma, taste, and overall acceptance of beverage. The test required 50 panelists and counterbalancing was also done to the samples. The test was done by using seven scales from 1 (extremely dislike) until 7 (extremely like)

\section{Statistical analysis}

All statistical analysis were done using SPSS version 17. Complete factorial randomized designs with two repetitions were applied to all experiments. For the extract preparation step, two factors were analyzed (solvent types and methods of extraction), for beverage preparation step, another two factors were analyzed (ratio of lemongrass extract to green tea and stevia level). Significant effects of factors are analyzed further using Duncan test. 


\section{RESULTS AND DISCUSSION}

\section{Prepared extract yield (\%)}

Figure 1 shows the result of yield (\%) for extracts obtained using solvents (distilled water, ethanol $80 \%$, and ethyl acetate $80 \%$ ) and two types of method (maceration and reflux). Based on statistical analysis result, there is a significant effect of interaction of solvent types and methods of extraction on yield $(\%)(\alpha=0.05)$.

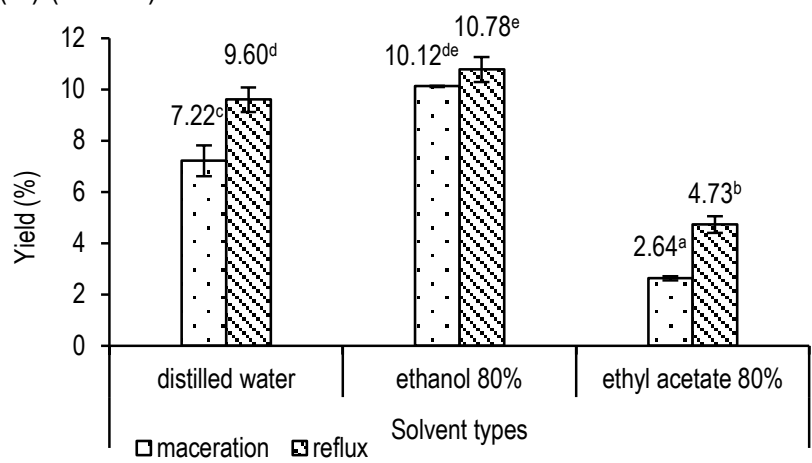

Note: Different superscript in the graph means there is significant difference a $a=0.05$

Figure 1. Effect of solvent types and methods of extraction on yield (\%)

It can be noted that reflux and maceration with ethanol as solvent resulted in highest yield (\%). Previous study showed that extraction using reflux results in higher amount of yield compared to maceration (Sultana et al. 2009). It is possible that heat generated during reflux destructs cell wall of lemongrass leaves so the content of cell leaks and dissolves in solvent extraction. It is important to note that yield (\%) does not represent antioxidant activity since the extract obtained is crude extract that may contains compounds other than antioxidant compounds. It was reported that organic solvent has ability to cleave hydrogen bond or hydrophobic bond between polyphenols and protein or polysaccharide in plant tissue (McManus et al. 1985) herefore organic solvent is suitable to extract polyphenols. On the other hand, polarity of solvent is responsible to determine type of extracted components (Islam, 2008). Ethanol is suitable to extract compounds with polar characteristic (Sultana et al. 2009). It can be inferred that polar compounds dominate lemongrass because the yield (\%) is the highest in extraction using ethanol.

\section{Total phenolic content of extracts}

The results of total phenolic content of extracts can be seen in Figure 2. Based on statistical analysis on total phenolic content of extracts, there is a significant effect of interaction of solvent types and methods of extraction $(a=0.05)$ on total phenolic content. Reflux extraction using ethanol as a solvent resulted in significantly higher total phenolics than other treatments $(126.66 \pm 4.59 \mathrm{mg} T A E / g$ extract). It can be inferred that phenolics present in lemongrass dissolve better in organic polar solvent. It was reported by Sultana et al. (2009) that regardless the extracting solvent used, total phenolic content of plant materials extracted using reflux technique is decreased. This might be caused by thermal decomposition of some phenolics. However different result was found in extraction of Vogel seeds under reflux using aqueous ethanol. It can be inferred that effective extraction condition varied among different plant phenolics. Antolovich et al. (2000) also studied that extraction under reflux condition can lead to the release of some bound phenolics, thus increase the amount of phenolics. Beside that, Iso-orientin and orientin, the two main water-soluble antioxidant compounds in lemongrass (Cheel et al. 2005) are able to withstand high temperature as high as spray drying (Viljouen, 2008). These explain the high total phenolic contents of extract under reflux treatments.

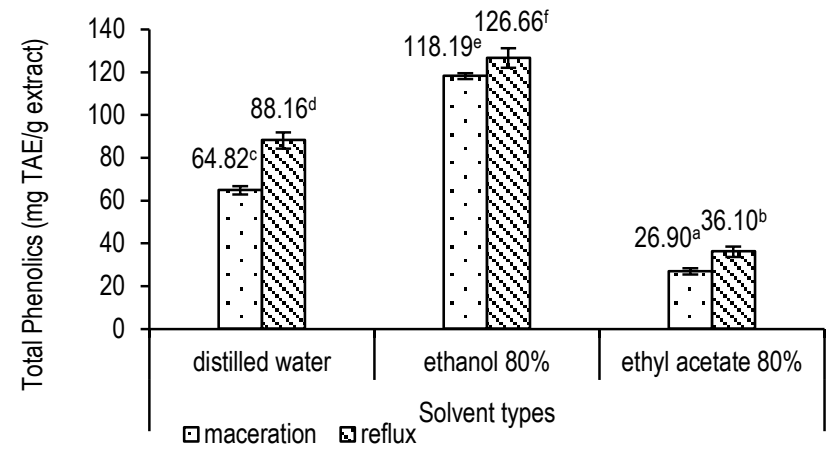

Note: Different superscripts indicate significant difference among treatments at $\alpha=0.05$

Figure 2. Effect of solvent types and methods of extraction on the total phenolic content of extracts

\section{Total flavonoid content of extracts}

The result of total flavonoid analysis of all extracts can be seen in Figure 3. Based on statistical analysis of total flavonoid content, there is a significant effect of interaction $(\alpha=0.05)$ of solvent types and methods of extraction on total flavonoid content. This result is in agreement with total flavonoids of Aloe barbadensis leaves and Ficus religiosa fruits that increased under reflux extraction with aqueous methanol and aqueous ethanol consecutively (Sultana et al. 2009).

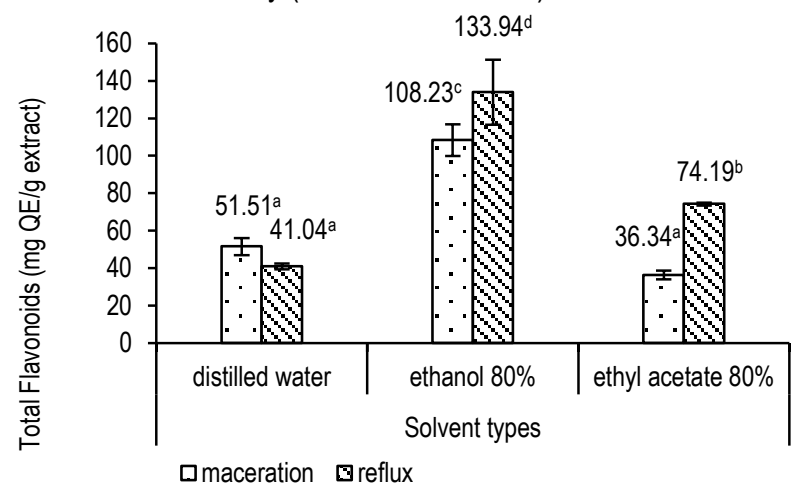

Note: Different superscripts indicate significant difference among treatments at $\alpha=0.05$

Figure 3. Effect of solvent types and methods of extraction on total flavonoid content of extract

\section{Antioxidant activity of extracts}

Solvent types and method of extraction gave significant effect towards antioxidant activity $(a=0.05)$. However, there is no 
significant effect of interaction of solvent types and methods of extraction ( $\alpha=0.05)$ on antioxidant activity of extracts. Effect of method on antioxidant activity is as shown in Table 1.

Table 1. Effect of solvent types and methods of extraction on antioxidant activity of extracts

\begin{tabular}{lc}
\hline \multicolumn{1}{c}{ Solvent Types } & $(\mathrm{a})$ \\
\hline Distilled water & $\mathrm{IC}_{50}(\mathrm{mg} / \mathrm{L})$ \\
Ethanol $(80 \%)$ & $199.32 \pm 16.77^{\mathrm{b}}$ \\
Ethyl acetate $(80 \%)$ & $103.73 \pm 8.03^{\mathrm{a}}$ \\
\hline
\end{tabular}

\begin{tabular}{cc}
\hline \multicolumn{1}{c}{ Methods of Extraction } & $\mathrm{IC}_{50}(\mathrm{mg} / \mathrm{L})$ \\
\hline Maceration & $186.19 \pm 61.48^{\mathrm{b}}$ \\
Reflux & $158.70 \pm 47.88^{\mathrm{a}}$ \\
\hline $\begin{array}{l}\text { Note: Different superscripts indicate significant differences among treatments at } \\
\mathrm{a}=0.05\end{array}$
\end{tabular}

Reflux method resulted in extract with statistically highest antioxidant activity (IC50 $158.70 \pm 47.88 \mathrm{mg} / \mathrm{L}$ ). Extract obtained using ethanol $80 \%$ as solvent also resulted in statistically highest antioxidant activity $\left(\mathrm{IC}_{50} 103.73 \pm 8.03 \mathrm{mg} / \mathrm{L}\right)$. Usually extraction under reflux results in extract with lower antioxidant activity as compared to maceration. However this is not solely the case. Previous study showed that ethanolic extracts of roots of Moringa oleifera, leaves of Aloe barbadensis, and fruit of Ficus religiosa obtained from reflux method has higher scavenging activity as compared with those of obtained from maceration method (Sultana et al. 2009). Reflux is suitable to extract sample that has resistance to high temperature.

It was reported that antioxidant activities of the plant materials are strongly correlated with nature of extracting solvents. Ethanol as a polar solvent is suitable to extract antioxidant compounds from various plants and plant-based foods such as plum, pomegranate, broccoli, rosemary, sage, rice bran, and citrus peel (Sultana et al. 2009). In this case ethanol is also suitable to extract antioxidant constituent of lemongrass since it resulted in extract with highest antioxidant activity.

\section{Phytochemicals of selected extract detected qualitatively}

Ethanolic extract obtained under reflux was chosen as extract with highest antioxidant activity and also chosen to be applied in beverages. Therefore, this extract was subjected to qualitative phytochemical test. The result of qualitative analysis on phytochemicals present in ethanolic extract obtained under reflux is as shown in Table 2. Result of qualitative analysis on lemongrass extract suggested that flavonoids present in more abundant level as compared to phenolics. In fact flavonoids is a part of phenolics so the amount of phenolics should be higher than flavonoids. It is important to be noted that one can not determine amount of compound through qualitative analysis. Since qualitative analysis merely serve as rough estimation of phytochemicals present in the extract. However qualitative analysis on phytochemical is also important to give information of compounds that might present in extract.
Table 2. Result of qualitative analysis of phytochemicals on lemongrass ethanolic extracts extracted using reflux method

\begin{tabular}{clc}
\hline Treatment & Compounds Analysed & Results \\
\hline Ethanol-reflux & Saponin & ++ \\
& Tannin & ++ \\
& Alkaloid & +++ \\
& Triterpenoid & ++ \\
& Steroid & - \\
& Phenolics & ++ \\
& Flavonoids & ++++ \\
& Glycoside & +++ \\
\hline Notes : - (negative); + (weakly detected); ++ (detected); +++ (strongly detected); \\
++++ (very strongly detected)
\end{tabular}

\section{Toxicity analysis on selected extract}

Toxicity analysis on ethanolic extract obtained under reflux was conducted to confirm the safety of extract considering the extract was applied to food product. Result of toxicity analysis was expressed as $L C_{50}$ with value of $289.23 \mathrm{ppm}$. According to Moshi et al. (2010), the brine shimp lethality test results are interpreted as non toxic when the value of $L C_{50}$ is higher than $100 \mathrm{ppm}$. The result of interpretation confirms the safety of extract to be consumed and therefore the extract can be applied to food product.

\section{Prepared beverage total phenolic content}

The result of total phenolic analysis of the beverages is shown in Figure 4. There is a significant effect of interaction $(a=$ 0.05 ) of lemongrass extract to green tea ratio and level of stevia in affecting total phenolic content of beverages. The ratio of lemongrass extract to green tea at 1:3 [w/w] and level of stevia at $600 \mathrm{ppm}$ resulted in statistically highest total phenolic content in the tested beverages $(446.93 \pm 12.61 \mathrm{mg} \mathrm{TAE} / \mathrm{g}$ beverages).

Interaction between ratio of lemongrass extract to green tea and level of stevia gave various effects regarding total phenolic content. It may be contributed by complex interaction among phenolics from lemongrass extract and green tea and glycosides from stevia present in mixture. Interestingly, stevia level at $600 \mathrm{ppm}$ resulted in highest phenolic in each lemongrass extract to green tea ratio. Jahan et al. (2010) found that total phenolics content from stevia leaves (Stevia rebaudiana) extracted with hot water is as much as $31.25 \pm 0.25$ $\mathrm{mg} \mathrm{GAE/g}$. Therefore, increasing amount of stevia might affect amount of total phenolic in beverages.

\section{Total flavonoid content of beverages}

The result of total flavonoid analysis can be seen in Figure 5. Based on statistical analysis, there is a significant effect of interaction $(\alpha=0.05)$ of lemongrass extract to green tea ratio and stevia level on total flavonoid content. Ratio of lemongrass extract to green tea at 1:1 [w/w]) and level of stevia at $600 \mathrm{ppm}$ resulted in statistically highest total flavonoid content beverage (144.25 $\pm 7.74 \mathrm{mg} \mathrm{QE} / \mathrm{g}$ beverage). Again, interaction between each constituent, in this case flavonoid constituent may occur and affect total flavonoid content in some ways either decrease or increase total flavonoid content. According to Hidalgo et al. (2010), it is well-known that flavonoids have tendency to bind each other when they are mixed together. It is possible that these bonds hinder the availability of flavonoid constituent to react with reagent during analysis. Hence it may decrease total flavonoid content analyzed. 


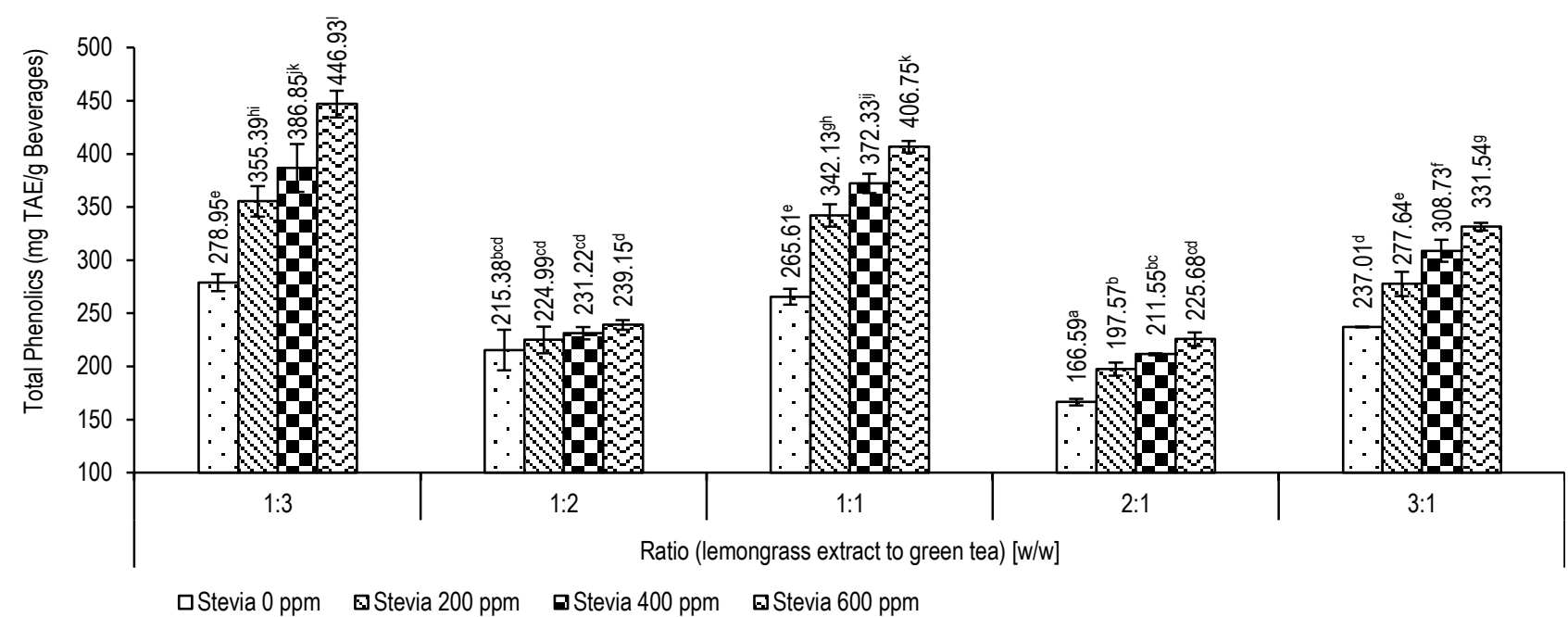

Note: Different superscript in the graph means there is significant difference at $a=0.05$

Figure 4. Effect of ratio of lemongrass extract to green tea and level of stevia on total phenolic content of beverages

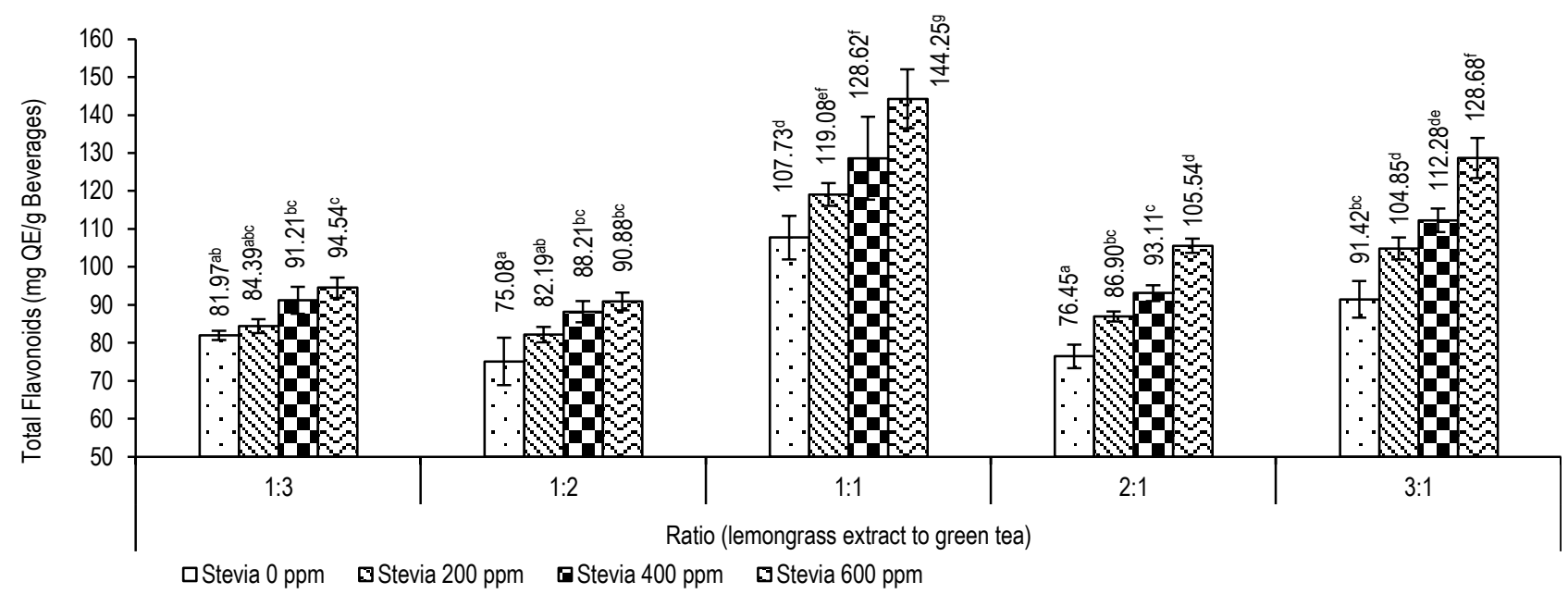

Note: Different superscript in the graph means there is significant difference at $a=0.05$

Figure 5. Effect of ratio of lemongrass extract to green tea and level of stevia on total flavonoid content of beverages

\section{Antioxidant activity of beverages}

Based on statistical analysis, there is no significant effect of interaction $(\alpha=0.05)$ of lemongrass extract to green tea ratio and level of stevia on antioxidant activity of beverages. Effect of lemongrass extract to green tea ratio and level of stevia to antioxidant activity of beverage can be seen in Table 3 .

Ratio of lemongrass extract to green tea at 1:3 and 1:1 [w/w] resulted in statistically highest antioxidant activity $\left(\mathrm{IC}_{50}\right.$ $271.84 \pm 44.48 \mathrm{mg} / \mathrm{L}$ and $287.15 \pm 36.25 \mathrm{mg} / \mathrm{L}$ respectively) among treatments. On the other hand, stevia level at $600 \mathrm{ppm}$ resulted in statistically highest antioxidant activity $(301.60 \pm 80.89$ $\mathrm{mg} / \mathrm{L}$ ) among treatments. Lemongrass extract to green tea ratio affected value of $\mathrm{IC}_{50}$ in various ways. It can be inferred from the result that chemical interactions or binding may be occurring among antioxidant components (Hidalgo et al. 2010) and leads to unpredictable result of antioxidant activity.
Study regarding antioxidant activity of combined flavonoid constituents revealed that combination of certain constituents may result in either synergistic or antagonistic interaction. Again, the result is unpredictable since there is no certain rule regarding either synergistically or antagonistically interacted combination (Hidalgo et al. 2010). For example, Kadoma et al. (2006) studied the synergistic interaction between epicathecin and epigallocatechin gallate (bioactive compounds in green tea) with tocopherols in an in vitro model. Meanwhile another study (Hidalgo et al. 2010) showed antagonistic interaction of antioxidant activity when epicathecin and epigallocatechin gallate were combined with myricetin and quercetin.

In comparison with vitamin $\mathrm{C}$, this beverage was less effective as antioxidant, which showed the $\mathrm{IC}_{50}$ of $4.14 \mathrm{ppm}$ (Witoko, 2012). On the other hand it is comparable with the $\mathrm{IC}_{50}$ of black tea, which is $288.60 \mathrm{ppm}$ (Moraes-de-Souza et al. 2008). 
Table 3. Effect of lemongrass extract to green tea ratio and level of stevia on antioxidant activity of beverages

\begin{tabular}{cc} 
& \\
\hline Lemongrass Extract to Green Tea Ratio $[\mathrm{w} / \mathrm{w}]$ & $\mathrm{I} \mathrm{C}_{50}(\mathrm{mg} / \mathrm{L})$ \\
\hline $1: 3$ & $271.84 \pm 44.48^{\mathrm{a}}$ \\
$1: 2$ & $352.28 \pm 31.42^{\mathrm{c}}$ \\
$1: 1$ & $287.15 \pm 36.25^{\mathrm{a}}$ \\
$2: 1$ & $484.55 \pm 51.37^{\mathrm{d}}$ \\
$3: 1$ & $317.67 \pm 30.95^{\mathrm{b}}$ \\
\hline
\end{tabular}

\begin{tabular}{|c|c|}
\hline Level of stevia (ppm) & $\mathrm{IC}_{50}(\mathrm{mg} / \mathrm{L})$ \\
\hline 0 & $387.57 \pm 87.28^{d}$ \\
\hline 200 & $354.15 \pm 81.04 c$ \\
\hline 400 & $327.48 \pm 81.30^{b}$ \\
\hline 600 & $301.60 \pm 80.89 a$ \\
\hline
\end{tabular}

Note: Different superscript in the graph means there is significant difference at $a=0.05$

\section{Hedonic test on beverages with best antioxidant activity}

Beverages selection for hedonic test was emphasized on antioxidant activity $\left(\mathrm{as}_{\mathrm{IC}} \mathrm{C}_{50}\right.$ ) of beverages. Beverages with best antioxidant activity were made with lemongrass extract to green tea ratio $[\mathrm{w} / \mathrm{w}]$ at 1:3, 1:1, 3:1, with level of stevia at $600 \mathrm{ppm}$.

Based on statistical analysis ( $\alpha=0.05)$, it can be seen that there is a significant effect of ratio of lemongrass extract to green tea on all parameters (colour, aroma, taste, and overall acceptance). Table 4 shows the effect of lemongrass extract to green tea ratio on colour, aroma, taste, and overall acceptance of beverages.

Table 4. Effect of lemongrass extract to green tea ratio on colour aroma, taste, and overall acceptance of beverages

\begin{tabular}{lccc}
\hline \multirow{2}{*}{ Hedonic Score } & \multicolumn{3}{c}{ Lemongrass Extract to Green Tea Ratio [w/w] } \\
\cline { 2 - 4 } & $1: 3$ & $1: 1$ & $3: 1$ \\
\hline Colour & $5.00 \pm 0.99^{\mathrm{ab}}$ & $5.22 \pm 0.82^{\mathrm{b}}$ & $4.60 \pm 1.29^{\mathrm{a}}$ \\
Aroma & $4.18 \pm 1.30^{\mathrm{a}}$ & $5.20 \pm 1.26^{\mathrm{b}}$ & $4.30 \pm 1.52^{\mathrm{a}}$ \\
Taste & $3.60 \pm 1.59^{\mathrm{b}}$ & $4.12 \pm 1.71^{\mathrm{b}}$ & $2.30 \pm 1.16^{\mathrm{a}}$ \\
Overall & $3.76 \pm 1.52^{\mathrm{b}}$ & $4.40 \pm 1.40^{\mathrm{c}}$ & $2.94 \pm 1.25^{\mathrm{a}}$
\end{tabular}

Note: Superscripts are to be read horizontally. Different superscripts among the same parameters indicate significant difference at $\mathrm{a}=0.05$

It can be seen that although beverage made with ratio of lemongrass extract to green tea $[\mathrm{w} / \mathrm{w}]$ at $1: 1$ was not significantly preferred as compared to beverage made with ratio (lemongrass extract to green tea [w/w]) 1:3, all attributes of this beverage were preferred by panel. It can be concluded that based on colour, aroma, taste, and overall acceptance this beverage was the most preferred by panel. The results also showed that the final product overall hedonic score is 4.4 (neutral to slightly liked), meaning there is an opportunity to improve its hedonic characteristic.

\section{CONCLUSION}

Solvent types and method of extraction interacts in affecting the yield (\%), total phenolic content, and total flavonoid content of extract. Reflux method and ethanol resulted in statistically $(\alpha=0.05)$ highest antioxidant activity among other treatments $\left(\mathrm{IC}_{50}=158.70 \pm 47.88 \mathrm{mg} / \mathrm{L}\right.$ for reflux method and $103.73 \pm 8.03$ $\mathrm{mg} / \mathrm{L}$ for ethanol).

Ratio of lemongrass extract to green tea and level of stevia have significant effect of interaction on total phenolic content and total flavonoid content, but not to antioxidant activity of beverages. Beverages with best formulation are determined based on highest antioxidant activity. Beverages made with ratio of lemongrass extract to green tea [w/w] at $1: 3$ and $1: 1$ and level of stevia 600 ppm were beverages with the highest antioxidant activity. Hedonic testing on beverages revealed that beverage made from ratio of lemongrass extract to green tea $[\mathrm{w} / \mathrm{w}]$ at $1: 1$ with addition of stevia at $600 \mathrm{ppm}$ was the most preferred regarding colour, aroma, and overall acceptance (neutral to slightly liked). Therefore, beverage made from ratio of lemongrass extract to green tea [w/w] at $1: 1$ can be produced commercially as it exhibited beneficial characteristics.

\section{REFERENCES}

Aja PM, Okaka ANC, Onu PN, Ibiam U, Urako AJ. 2010. Phytochemical composition of Talinum triangulare (water leaf) leaves. Pak J Nutr 9: 527-530. DOl: 10.3923/ pjn.2010.527.530

Antolovich M, Prenzler P, Robards K, Ryan D. 2000. Sample preparation in the determination of phenolic compounds in fruits. Analyst 125: 989-1009. DOI: 10.1039/B000080l.

Cheel J, Theoduloz C, Rodriaguez J, Schmeda-Hirschmann G. 2005. Free radical scavengers and antioxidants from lemongrass (Cymbopogon citratus (DC.) Stapf.). J Agr Food Chem 53: 2511-2517. DOI: 10.1021/jf0479766.

Harborne JB. 1996. Metode Fitokimia: Penuntun Cara Modern Menganalisis Tumbuhan. Bandung: Institut Teknologi Bandung.

Hidalgo M, Sánchez-Moreno C, de Pascual-Teresa S. 2010. Flavonoid-flavonoid interaction and its effect on their antioxidant activity. J Food Chem 121: 691-696. DOI: 10.1016/j.foodchem.2009.12.097.

Jahan IA, Mostafa M, Hossain H, Nimmi I, Sattar A, Alim A, Moeiz SMI. 2010. Antioxidant activity of Stevia rebaudiana Bert. leaves from Bangladesh. Bangladesh Pharm J 13: 6775

Juniarti OD, Yuhenita. 2009. Kandungan senyawa kimia, uji toksisitas (brine shrimp lethality test) dan antioksidan (1.1diphenyl-2-pikrilhydrazyl) dari ekstrak daun saga (Abrus precatorius L.). Makara Sains 13: 50-54.

Juntachote T, Berghofer E, Bauer F, Siebenhandl S. 2006. The application of response surface methodology to the production of phenolic extracts of lemon grass, galangal, holy basil and rosemary. Int J Food Sci Tech 41: 121-133. DOI: 10.1111/j.1365-2621.2005.00987.x.

Kadoma Y, Ishihara M, Okada N, Fujisawa S. 2006. Free radical interaction between vitamin $\mathrm{E}$ (alpha-, beta-, gamma- and delta-tocopherol), ascorbate and flavonoids. In vivo 20: 823 -827 . 
Kirakosyan A, Seymour EM, Noon KR, Llanes DEU, Kaufman PB, Warber SL, Bolling SF. 2010. Interactions of antioxidants isolated from tart cherry (Prunuscerasus) fruits. J Food Chem 122: 78-83. DOl: 10.1016/j.foodchem. 2010.02.017.

Madan S, Ahmad S, Singh GN, Kohli K, Kumar Y, Singh R, Garg M. 2010. Stevia rebaudiana (Bert.) Bertoni - A review. Indian J Nat Product Resource 1: 267-286.

Makkar, Harinder PS, Siddhuraju P, Becker K. 2007. Plant Secondary Metabolites. New Jersey: Springer Science + Business Media, LLC.

McManus JP, Davis KG, Beart JE, Gaffney SH, Lilley TH, Haslam E. 1985. Polyphenol Interactions. Part 1. Introduction; Some Observations on the Reversible Complexation of Polyphenols with Proteins and Polysaccharides. J Chem Soc Perkin Trans 2: 1429 - 1438. DOI: 10.1039/P29850001429

Meda A, Lamien CE, Romito M, Millogo J, Nacoulma OG. 2005 Determination of the total phenolic, flavonoid and proline contents in Burkina Fasan honey, as well as their radical scavenging activity. J Food Chem 91: 571-577. DOI: 10.1016/j.foodchem.2004.10.006.

Moraes-de-Souza, Oldoni RATLC, Regitano-d'Arce MAB, Alencar SM. 2008. Antioxidant activity and phenolic composition of herbal infusions consumed in Brazil. Cienc Tecnol Aliment 6: 41-47. DOI:10.1080/ 1135812080 9487626 .

Moshi MJ, Innocent E, Magadula JJ, Otieno DF, Weisheit A, Mbabazi PK, Nondo RSO. 2010. Brine shrimp toxicity of some plants used as traditional medicines in Kagera Region, north western Tanzania. Tanzan J Health Res 12: 63-67.
Puatanachokchai R, Kishida H, Denda A, Murata N, Konishi Y, Vinitketkumnuen U, Nakae D. 2002. Inhibitory effects of lemon grass (Cymbopogon citratus, Stapf) extract on the earlyphase of hepatocarcinogenesis after initiation with diethylnitrosaminein male Fischer 344 rats. Cancer Lett 183: 9-15. DOI: 10.1016/S0304-3835(02)00111-8.

Shim JU, Lim KT. 2009. Antioxidative activity of glycoprotein isolated from Geranium sibiricum Linne. Nat Prod Res 23: 375-387. DOI: 10.1080/14786410802228447.

Sultana B, Anwar F, Ashraf M. 2009. Effect of extraction solvent/technique on the antioxidant activity of selected medicinal plant extracts. Molecules 14: 2167-2180. DOI: 10.3390/molecules 14062167.

Tachakittirungrod S, Okonogi S, Chowwanapoonpohn S. 2007. Study on antioxidant activity of certain plants in Thailand: Mechanism of antioxidant action of guava leaf extract. $J$ Food Chem 103: 381-388. DOI: 10.1016/j.foodchem. 2006.07.034.

Tagami K, Uchida S, Ishii N. 2012. Extractability of radiocesium from processed green tea leaves with hot water: the first emergent tea leaves harvested after the TEPCO's Fukushima daiichi nuclear power plant accident. J Radioanal Nucl Ch 292: 243-247. DOl: 10.1007/s10967011-1398-y.

Viljoen M. 2008. The Stability of Aspalathin, Iso-Orientin and Orientin in Rooibos Iced Tea [Thesis]. South Africa: Faculty of Agrisciences, Stellenbosch University.

Witoko MC. 2012. Beverage Formulation Based on Rambutan (Nephelium lappaceum L.) Rind Extract [Thesis]. Karawaci: Faculty of Industrial Technology, Universitas Pelita Harapan.

Yu L. 2008. Wheat Antioxidant. Canada: Wiley. 